\title{
Chitosan and Aloe vera gel formulations as wound healing agents in episiotomy
}

\author{
Géis de quitosana e Aloe vera como agentes de cicatrização pós-episiotomia \\ Formulaciones de gel de quitosano y Aloe vera como agentes cicatrizantes de heridas en la \\ episiotomía
}

Received: 04/10/2021 | Reviewed: 04/17/2021 | Accept: 05/13/2021 | Published: 05/20/2021

\author{
Maria Dennise Medeiros Macêdo \\ ORCID: https://orcid.org/0000-0003-2990-5447 \\ Federal University of Campina Grande, Brazil \\ E-mail: dennisemed1@gmail.com \\ Hiago Kartney Belarmino Dantas \\ ORCID: https://orcid.org/0000-0001-9168-5049 \\ Federal University of Campina Grande, Brazil \\ E-mail: hiagobelarmino@gmail.com \\ Matheus Ferreira de Souza \\ ORCID: https://orcid.org/0000-0002-2191-2573 \\ Federal University of Campina Grande, Brazil \\ E-mail: matheusferza@gmail.com \\ Thiago Cajú Pedrosa \\ ORCID: https://orcid.org/0000-0002-8801-8322 \\ Federal University of Campina Grande, Brazil \\ E-mail: thiago.cajupedrosa@gmail.com \\ Ana Caroline Santana de Azevedo \\ ORCID: https://orcid.org/0000-0002-6732-8372 \\ Federal University of Campina Grande, Brazil \\ E-mail: ana.santana@certbio.ufcg.edu.br \\ Valeria Pereira Ferreira \\ ORCID: https://orcid.org/0000-0002-7845-6513 \\ Federal University of Campina Grande, Brazil \\ E-mail: valeriap.ferreira@ hotmail.com \\ Breno de Medeiros Lucena \\ ORCID: https://orcid.org/0000-0002-0673-4000 \\ Federal University of Campina Grande, Brazil \\ E-mail: brenolucena.bl@gmail.com \\ Wladymyr Jefferson Bacalhau de Sousa \\ ORCID: https://orcid.org/0000-0002-3931-8265 \\ Federal University of Campina Grande, Brazil \\ E-mail: wladymyrjb@yahoo.com.br \\ Marcus Vinicius Lia Fook \\ ORCID: https://orcid.org/0000-0002-8566-920X \\ Federal University of Campina Grande, Brazil \\ E-mail: marcus.liafook@certbio.ufcg.edu.br
}

\begin{abstract}
Episiotomy is an obstetric technique that consists of making an incision in the perineum during vaginal childbirth, to facilitate the baby to pass through. After delivery, the perineal region is sutured with absorbable threads to heal the cut. However, are frequent reports of pain, infections, and dyspareunia after the execution of this technique. In this context, the use of biomaterials becomes relevant as they promote faster and safer tissue repair, making it an attractive alternative for the healing process of episiotomy. Based on the physical-chemical and biological properties of chitosan and Aloe vera, this research developed three different vaginal gels, with the purpose of promoting tissue regeneration and infection prevention post-episiotomy. Chitosan solutions with concentrations of 5\% w/v were prepared by dissolving the chitosan powder in $2 \% \mathrm{v} / \mathrm{v}$ aqueous solution of acetic acid. After the extraction and processing of the mucilage, the pulp of the Aloe vera leaf was added to the chitosan gel in the proportions of 1, 2, and 3\% v/v. All formulations were neutralized by the slow drip technique of a neutralizing solution of sodium hydroxide $(2 \mathrm{M})$. The compositions were analyzed according to their organoleptic aspect, optical microscopy, spreadability, hydrogen potential, absorption spectroscopy, cytotoxicity, and rheological behavior. Based on the results obtained, it was possible to conclude that gels produced have the potential to be used as vaginal gels.
\end{abstract}

Keywords: Episiotomy; Tissue regeneration; Vaginal gel; Chitosan; Aloe vera. 


\section{Resumo}

A episiotomia é uma técnica obstétrica que consiste na execução de uma incisão no períneo durante o parto vaginal, com o intuito de facilitar a saída do feto. Após o parto, a região perineal é suturada com fios absorvíveis para cicatrização do corte. Entretanto, são frequentes os relatos de dor, infecções e dispaurenia após a execução desse procedimento, cuja incidência é maior em primíparas. Nesse contexto, o uso dos biomateriais tem se mostrado relevante no sentido de possibilitar o reparo mais rápido e seguro dos tecidos, tornando-se uma alternativa atrativa para o processo cicatricial da episiotomia. Sabendo-se das propriedades físico-químicas e biológicas da quitosana e da Aloe vera, essa pesquisa teve como objetivo desenvolver um gel vaginal para uso pós-episiotomia, visando sua aplicação como agente coadjuvante no processo de regeneração tecidual e controle de infecções. As composições foram preparadas a partir de uma solução de quitosana $(5 \% \mathrm{~m} / \mathrm{v})$, dissolvida em solução aquosa de ácido acético (2\% v/v). Após extração e processamento da mucilagem, a polpa da folha de Aloe vera foi adicionada ao gel de quitosana nas proporções de 1, 2 e $3 \%(\mathrm{v} / \mathrm{v})$. Todas as formulações foram neutralizadas pela técnica do gotejamento lento de uma solução neutralizante de hidróxido de sódio $(2 \mathrm{M})$. As composições foram analisadas em função de seu aspecto organoléptico, microscopia óptica, espalhabilidade, potencial hidrogeniônico, espectroscopia de absorção, citotoxicidade e comportamento reológico. Com base nos resultados obtidos foi possível concluir que géis produzidos exibem potencial para serem utilizados como géis vaginais.
\end{abstract}

Palavras-chave: Episiotomia; Regeneração tecidual; Gel vaginal; Quitosana; Aloe vera.

\title{
Resumen
}

La episiotomía es una técnica obstétrica que consiste en realizar una incisión en el perineo durante el parto vaginal, con el fin de facilitar la salida del feto. Después del parto, la región perineal se sutura con hilos absorbibles para curar el corte. Sin embargo, hay informes frecuentes de dolor, infecciones y dispaurenia después de realizar este procedimiento, cuya incidencia es mayor en mujeres primíparas. En este contexto, se ha demostrado que el uso de biomateriales es relevante para permitir una reparación tisular más rápida y segura, lo que la convierte en una alternativa atractiva para el proceso de curación de la episiotomía. Conociendo las propiedades físico-químicas y biológicas del quitosano y el Aloe vera, esta investigación tuvo como objetivo desarrollar un gel vaginal para uso post-episiotomía, con el objetivo de su aplicación como agente de apoyo en el proceso de regeneración tisular y control de infecciones. Las composiciones se prepararon a partir de una solución de quitosano (5\% p/v), disuelta en una solución acuosa de ácido acético $(2 \%$ v/v). Después de la extracción y procesamiento del mucílago, se agregó la pulpa de la hoja de Aloe vera al gel de quitosano en las proporciones de 1, 2 y $3 \%$ (v/v). Todas las formulaciones se neutralizaron mediante la técnica de goteo lento de una solución neutralizante de hidróxido de sodio (2 M). Las composiciones se analizaron según su aspecto organoléptico, microscopía óptica, esparcimiento, potencial hidroiónico, espectroscopía de absorción, citotoxicidad y comportamiento reológico. Con base en los resultados obtenidos, fue posible concluir que los geles producidos tienen potencial para ser utilizados como geles vaginales.

Palabras clave: Episiotomía; Regeneración de tejidos; Gel vaginal; Quitosano; Aloe vera.

\section{Introduction}

Episiotomy is an cirurgical incision made in the perineal muscles during vaginal delivery to facilitate the exit of the fetus. It is an obstetric method used worldwide and developed in 1741 by Ould. For decades it was thought that episiotomy helped to prevent more extensive vaginal lacerations, preserved the muscular support of the pelvic floor and healed faster than natural lacerations. However, based on numerous clinical studies, it was concluded that episiotomies do not prevent those problems, and the routine implementation of the technique is no longer recommended in several countries. The procedure, however, can still be performed, as long as it's real need is proven (Kalis et al., 2012).

At the end of delivery, the health professional performs the episiorrhaphy, a technique that consists of stitching the vaginal mucosa with absorbable threads. Due to the small sewing, it is commonly admitted that this operation does not cause problems for mothers, although the perineal area is used in common activities such as sitting, walking, standing, and urinating. However, reports of pain, infections, and dyspareunia are frequent, with a higher incidence in primiparous women (Fernando et al., 2013; Sioutis, Thakar, \& Sultan, 2017; Verghese et al., 2016).

Regarding perineal healing, Cavanaugh wrote that the perineum must heal as quickly as possible, since this part cannot be observed directly by the mother and leads to an increase in maternal complications. Throughout history, several actions have been proposed to speed up the healing of episiorrhaphy; the use of a round head needle and suture threads with high absorbability, asepsis techniques, administration of antibiotics, and vaginal creams for pain relief. In this context, the use 
of biomaterials emerges as an attractive alternative in the healing process of episiorrhaphy. Due to the chemical similarity between biomaterials and the extracellular constituents of several biological tissues, these materials exhibit high biocompatibility, increasing the residence time in the tissue and contraction of the wound (Eghdampour et al., 2013; Santos et al., 2018).

One of the polymers used for this purpose is chitosan, a biocompatible, biodegradable, and antimicrobial biopolymer obtained from the partial deacetylation of chitin. The chitosan amino and hydroxyl groups adhere to vaginal mucus through two mechanisms: the first, by establishing hydrogen bonding bonds; and the second, due to the electrostatic attraction produced by the protonation of these groups in an acidic environment, typical of the vaginal region. The versatility of chitosan allows its conformation in different forms as fibers, scaffolds, membranes, spheres and gels. Besides that, its properties can be optimized in conjunction with other materials such as Aloe vera (Valenta, 2005).

Aloe vera is a succulent plant species of the genus Aloe native to North Africa. Considered one of the most important medicinal species, this plant has been used to treat various diseases since ancient times. It has a healing, analgesic, antimicrobial, purgative, moisturizing, and anti-inflammatory action, attributed to the presence of salicylic acid and the oxidation of arachidonic acid promoted by its constituents. Given its regenerative properties, the use of Aloe vera in vaginal applications, especially episiorrhaphy, is very promising (Teplicki et al., 2018). In this context, this study developed three different chitosan and Aloe vera vaginal gels for use as an adjunct therapeutic agent in the healing and infection control process after episiotomy.

\section{Methodology}

The methodology used to produce the chitosan gel was based on the work of Ribeiro et al. (2009). Initially, an aqueous solution of acetic acid was prepared $(2 \% \mathrm{v} / \mathrm{v})$. To prepare the chitosan gel, chitosan was gradually added to the acid solution until the final concentration reached $5 \% \mathrm{w} / \mathrm{v}$, under mechanical stirring $(200 \mathrm{rpm})$ at room temperature $\left(25^{\circ} \mathrm{C} \pm 1.5\right)$. After the complete dissolution of the chitosan, the gel was centrifuged at $3200 \mathrm{rpm}$ for $3 \mathrm{~min}$, also at room temperature, for removal of bubbles. The Aloe vera used in the vaginal gels was obtained from the pulp of the leaf. After cutting and peeling the leaf, the mucilage was extracted and processed in a blender $(50-60 \mathrm{~Hz}$ and $550 \mathrm{~W})$, in 2 pulses of $30 \mathrm{~s}$. The pulp was sieved, stored in an airtight plastic container, and refrigerated at $8^{\circ} \mathrm{C} \pm 2.0$.

Three different compositions were formulated by fixing the concentration of chitosan and varying de concentration of Aloe vera. Their respective codes are displayed below, in Table 1. The incorporation of Aloe vera was performed manually with a glass stick. All formulations were neutralized by slow drip of neutralizing solution $(\mathrm{NaOH}, 2 \mathrm{M})$ at the rate of one drop of solution per minute ( $1 \mathrm{drop} /$ minute) until reaching a $\mathrm{pH}$ of $\approx 7.0$ under constant agitation $(50 \mathrm{rpm})$, a methodology adapted from Llanos et al. (2015).

Table 1. Compositions of different formulations of Chitosan and Aloe vera vaginal gels.

\begin{tabular}{c|c|c}
\hline Formulation & \% Chitosan (w/v) & \% Aloe vera (v/v) \\
\hline GQA1 & 5 & 1 \\
\hline GQA2 & 5 & 2 \\
\hline GQA3 & 5 & 3 \\
\hline
\end{tabular}

Source: Authors.

The organoleptic analysis of the gels was performed to evaluate the characteristics detectable by sight and smell. Visual inspection was carried out to identify the presence of precipitates, turbidity, and phase separation. 
Optical microscopy was used to evaluate the morphology of the compositions. The analysis was performed with a Hirox Optical Microscope (KH-1300, MX(G)-5040Z, transmission mode), in 50, 100 and 200x. The hydrogen potential (pH) of the samples was determined by a ph meter. The equipment was previously calibrated with buffer solutions of 4.0 and 7.0 $\mathrm{pH}$. The analysis was performed directly, without dissolution of the sample and in triplicate. The compositions developed were subjected to analysis by Fourier Transform Infrared Spectroscopy (FTIR) in the Spectrum 400 infrared spectrophotometer (Perkin Elmer). The spectroscopy was performed to identify the functional groups present in the samples and their possible chemical interactions, using a scanning range from 4000 to $650 \mathrm{~cm}^{-1}, 32$ scans and a resolution of $4 \mathrm{~cm}^{-1}$. The spreadability of the gels was executed by measuring the sample diameters with a digital caliper (Absolute Digimatic, Mitutoyo). The measurements were performed as soon as gels were deposited on a glass plate at intervals of 20, 40, and 60 minutes. For this test, three repetitions were performed for each sample.

The evaluation of in vitro cytotoxicity of the tubes was performed by the MTT test [viability assessment test of fibroblasts [3-(4,5-dimethylthiazol-2-yl) -2,5-diphenyl-tetrazolium bromide], according to ISO 10993-5:2009. The material substrate was in direct contact with the cell line (L929, acquired from the Rio de Janeiro Cell Bank). The parameters observed in the test were the percentage of cell death. The rheological behavior of the vaginal gels were analyzed by rheometer (Thermo Fisher Scientific, plate/plate geometry, $35 \mathrm{~mm}$ diameter). A gap of $0.5 \mathrm{~mm}$ was used, as indicated by the software of the equipment. The flow and viscosity curves were obtained by determining the stress and viscosity as a function of the shear rate, respectively. The shear rate varied between 10 and $2000 \mathrm{~s}^{-1}$, according to the methodology proposed by Şenyigit et al. (2014). The storage $\left(G^{\prime}\right)$ and loss (G’) modules were calculated after determining the linear viscoelastic region of the gels, from 0.1 to $10 \mathrm{~Hz}$.

\section{Results and Discussion}

The developed vaginal gels showed a translucent aspect, as shown in Figure 1. Small whitish filaments were observed dispersed in the matrix.

Figure 1. Macroscopic analysis of vaginal chitosan and Aloe vera gels.

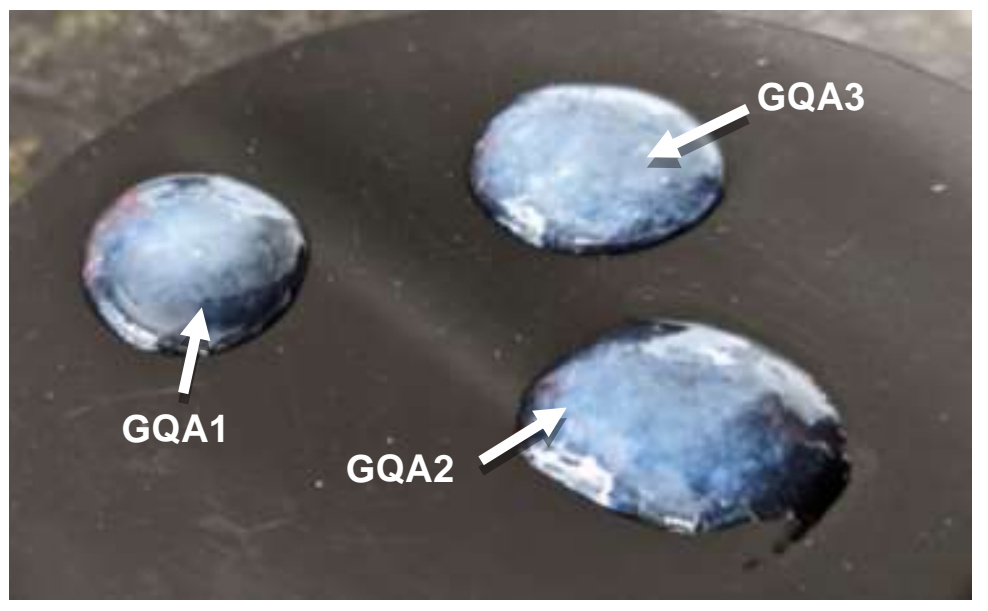

Source: Authors.

The origin of these fibers may be related to the mucilaginous structural arrangement present in the pulp of the Aloe vera leaf, constituted mainly by polysaccharides (Wang et al., 2017). It was not possible to detect the presence of crystals, phase separation, precipitates, or odor in any formulation. The compositions exhibited less translucency as the concentration of 
Aloe vera in the gels increased.

Through the morphological analysis of the samples, it was possible to evaluate the structural organization of the vaginal gels, as shown in Figure 2.

Figure 2. Microscopic analysis of vaginal chitosan and Aloe vera gels with magnification of 50x (a), 100x (b) and 150x (c).
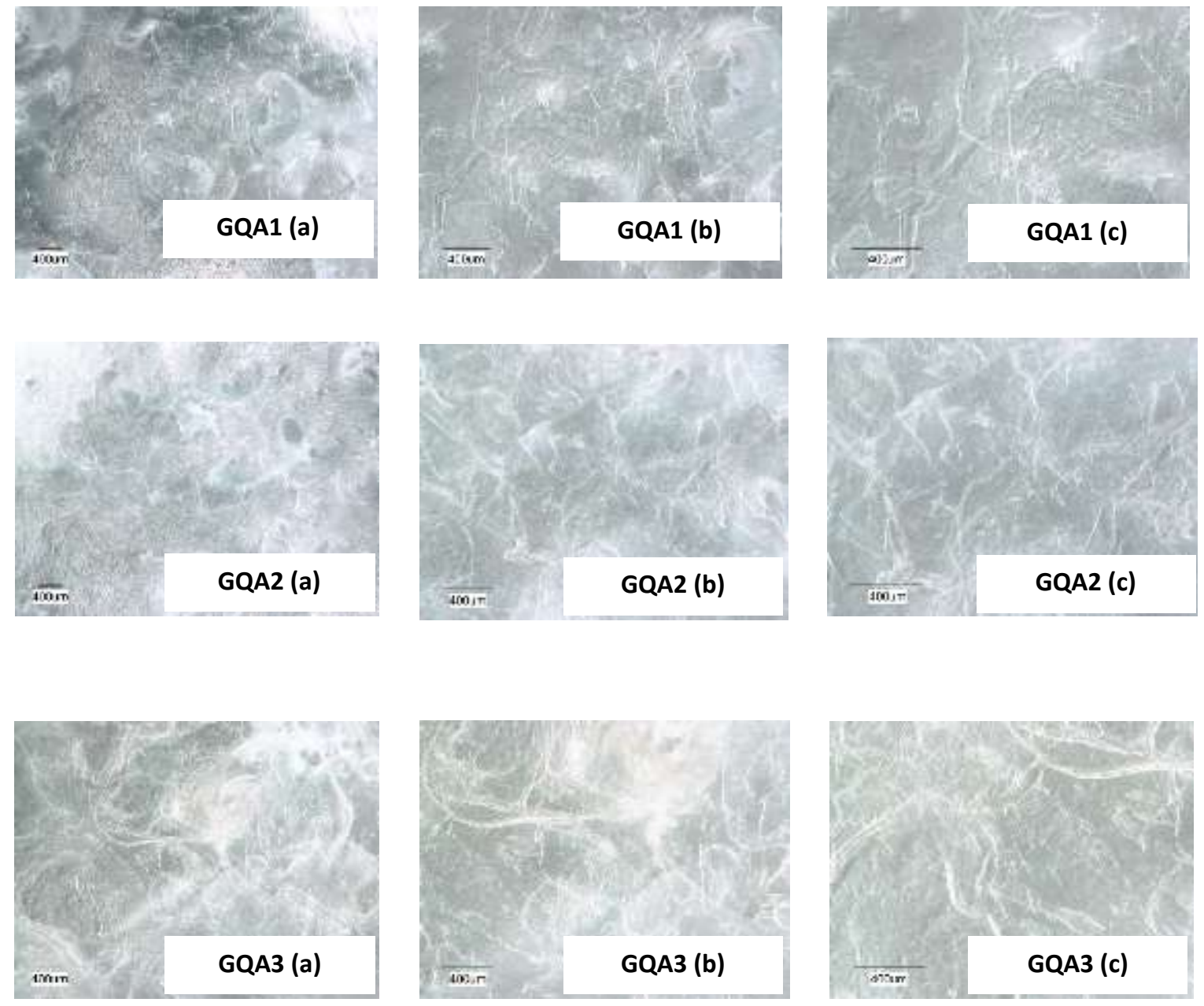

Source: Authors.

In all compositions, for all magnifications, the surface of the gels was smooth, translucent, without bubbles or cracks. It was noticed that the number of whitish filaments observed in the samples was proportional to the increase in the concentration of Aloe vera used. This result may be related to the decrease in the translucency of the gels, corroborating with the results of the visual analysis. Similar fibrous structures were found by Wang et al. (2017) when developing a metallocene polyethylene nanocomposite coated with Aloe vera, and Sharma (2018) with PVA nanofibers containing honey bee and Aloe vera for use as a wound dressing.

The vaginal $\mathrm{pH}$ of healthy women of reproductive age is acidic, ranging from 3.5 to 4.5 . Such acidity is responsible for maintaining the lactobacilli present in the vagina, which plays an important role in controlling inflammation and infections (Santos, 2019). In light of that, the determination of the $\mathrm{pH}$ of the developed gels is considered one of the important parameters for vaginal compatibility. However, due to episiotomy, that acidity can be considered a negative aspect, as it promotes burning at the application site. This factor was taken into account as a parameter while evaluating the $\mathrm{pH}$ of the formulations. 
As shown in Table 2, all formulations developed exhibited $\mathrm{pH}$ values suitable for the vaginal application, ranging from 6.99 to 7.03. It was also observed that the $\mathrm{pH}$ value of the gels did not change significantly with the use of different concentrations of Aloe vera $(\mathrm{p}<0.05)$.

Table 2. PH values of chitosan and Aloe vera gels.

\begin{tabular}{c|c}
\hline Formulation & pH + SD \\
\hline GQA1 & $7,03 \pm 0,02$ \\
\hline GQA2 & $6,99 \pm 0,03$ \\
\hline GQA3 & $7,01 \pm 0,01$ \\
\hline
\end{tabular}

Source: Authors.

Bonferoni et al. (2005) found $\mathrm{pH}$ values ranging from 4.0 to 6.0 when studying the effect of the formulation parameters used in the manufacture of mucoadhesive vaginal gels based on chitosan, and acetic or lactic acids. Wu and Li (2020) found that the $\mathrm{pH}$ value range of vaginal poloxamer and chitosan hydrogels varied from 4.0 to 4.8 when using acetic acid as a solvent. In these studies, however, no neutralization procedure was carried out.

The infrared spectra obtained from the chitosan powder sample, Aloe vera pulp and vaginal chitosan and Aloe vera gels are illustrated below, in Figure 3.

Figure 3. FTIR spectrum of chitosan powder $(\mathrm{CH})$, Aloe vera (AV) and Chitosan and Aloe vera gels.

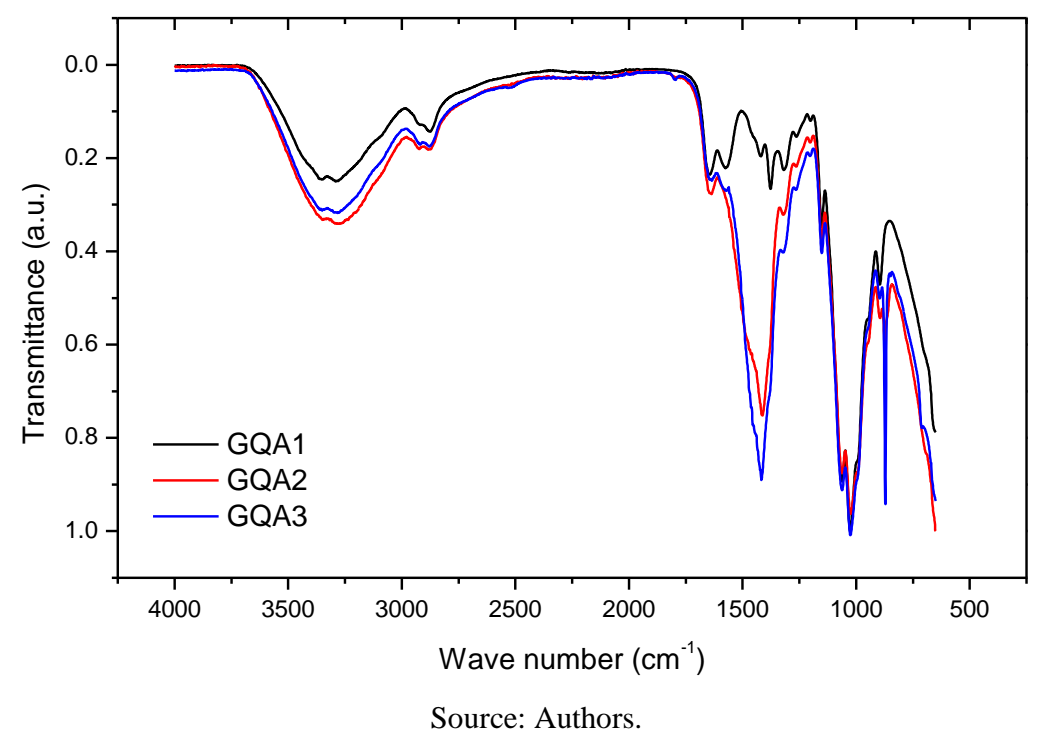

An amino group band was observed in the chitosan powder spectra, located in the region of $3343 \mathrm{~cm}^{-1}$. This band is superimposed by the absorption band resulting from the $-\mathrm{OH}$ group, at $3287 \mathrm{~cm}^{-1}$. According to the spectrum, were observed in 2913 and $2866 \mathrm{~cm}^{-1}$ characteristic bands of stretching vibrations of $-\mathrm{CH}_{2}$ and $-\mathrm{CH}_{3}$; at 1652 and $1574 \mathrm{~cm}^{-1}$, deformational vibration bands of the $\mathrm{N}-\mathrm{H}$ bond. It was also possible to identify the stretching vibration of C-O-C bonds at 1151 and $896 \mathrm{~cm}^{-1}$ and the C-O group, at 1060 and $1025 \mathrm{~cm}^{-1}$, typical vibrations of the chitosan saccharide structure (Liu, Chen and Park, 2005).

When analyzing the spectrum of Aloe vera, a hydroxyl group band was observed at $3299 \mathrm{~cm}^{-1}$. It was also possible to verify the axial deformation of $\mathrm{C}=\mathrm{O}$ at $1641 \mathrm{~cm}^{-1}$, at $1395 \mathrm{~cm}^{-1}$ the angular deformation of $\mathrm{C}-\mathrm{H}$, and at 1086 and $1048 \mathrm{~cm}^{-1} \mathrm{due}$ to axial deformation of C-O-C. The spectra of the chitosan and Aloe vera gels showed characteristic bands of both components, with an increase in the absorption intensity of the bands located at 1422 and $872 \mathrm{~cm}^{-1}$, related to the symmetric 
angular deformation of the $-\mathrm{CH}_{2}$ group and angular deformation of the $\mathrm{CH}$ group. These results agree with KhoshgozaranAbras et al. (2012), whose study aimed to develop chitosan membranes with different concentrations of Aloe vera.

By studying the spreadability of the gels, it was possible to conclude that the composition containing the highest proportion of Aloe vera, GQA3, exhibited the greatest spreadability among the formulations developed. The spreadability measure varied according to the formulations, obtaining higher values as the concentration of Aloe vera increased, as shown in Table 3.

Table 3. Spreadability of vaginal gels (\%) at fixed periods of time (min).

\begin{tabular}{c|c|c|c}
\hline Formulation & $\mathbf{2 0} \boldsymbol{\operatorname { m i n }}(\boldsymbol{\%})$ & $\mathbf{4 0} \boldsymbol{\operatorname { m i n }}(\boldsymbol{\%})$ & $\mathbf{6 0} \boldsymbol{\operatorname { m i n }}(\boldsymbol{\%})$ \\
\hline GQA1 & $2,02 \pm 0,32$ & $2,05 \pm 0,17$ & $2,08 \pm 0,22$ \\
\hline GQA2 & $2,16 \pm 0,27$ & $2,19 \pm 0,11$ & $2,23 \pm 0,33$ \\
\hline GQA3 & $2,20 \pm 0,28$ & $2,27 \pm 0,46$ & $2,32 \pm 0,19$ \\
\hline
\end{tabular}

Source: Authors.

The spreading time of a gel can be related to its thixotropic characteristic, a phenomenon in which a colloidal system changes its state from gel to sun or sun to gel. That is considered one of the key factors in the preparation of pharmaceutical formulations since the viscosity of the product can difficult its application (MASTROPIETRO, 2003). In this study, the spreadability of all compositions remained approximately constant, in the periods of time of 20, 40 and 60 minutes of exposition.

The percentage of cell viability displayed by the formulations is displayed in Figure 4. According to the minimum viability value determined by the ISO 10993-5:2009, which is 70\%, it was possible to conclude that all formulations proposed are viable for use in organic medium. Sánchez-Shancez et al. (2015), who developed bioadhesive vaginal gels of chitosan and kappa-carrageenan for controlled release of acyclovir found cell viability results similar to this study, with all compositions classified as biocompatible. The cell lines used in their study were lymphoblastic and uterus epithelial cell lines (MT-2, HEC1A). Similarly, Jalalvandi and Shavandi (2018) found percentages of cell viability (MSCs, passage 5) greater than $80 \%$ for chitosan- gluconate dihydrate and doxorubicin hydrochloride gels.

Figure 4. Cell viability of Chitosan and Aloe vera gels.

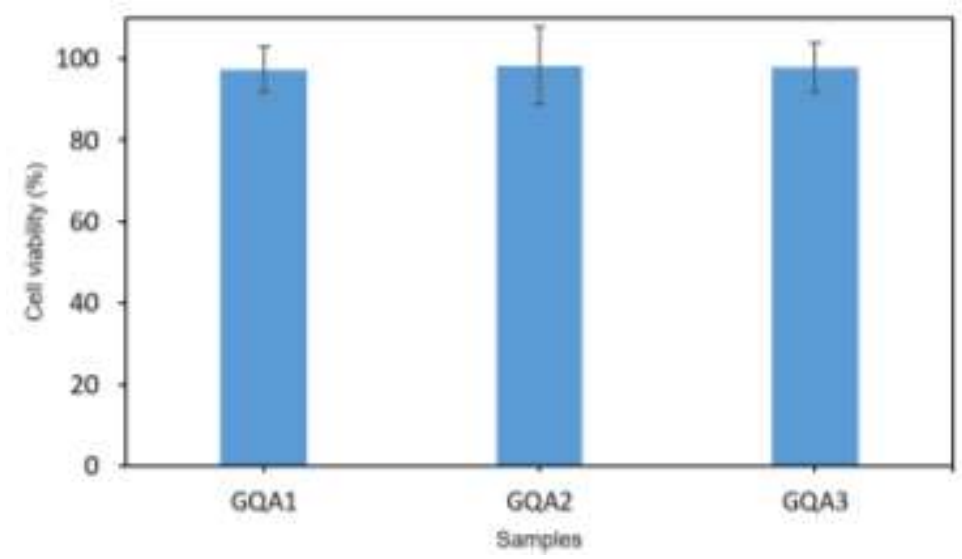

Source: Authors. 
As illustrated in Figure 5, the three formulations exhibited a decrease in apparent viscosity with an increase in the shear rate. Therefore, it was possible to classify the gels as non-Newtonian pseudoplastic systems (CAMPOS et al., 2020).

Figure 5. Flow curves (shear stress and viscosity) of Chitosan and Aloe vera gels.
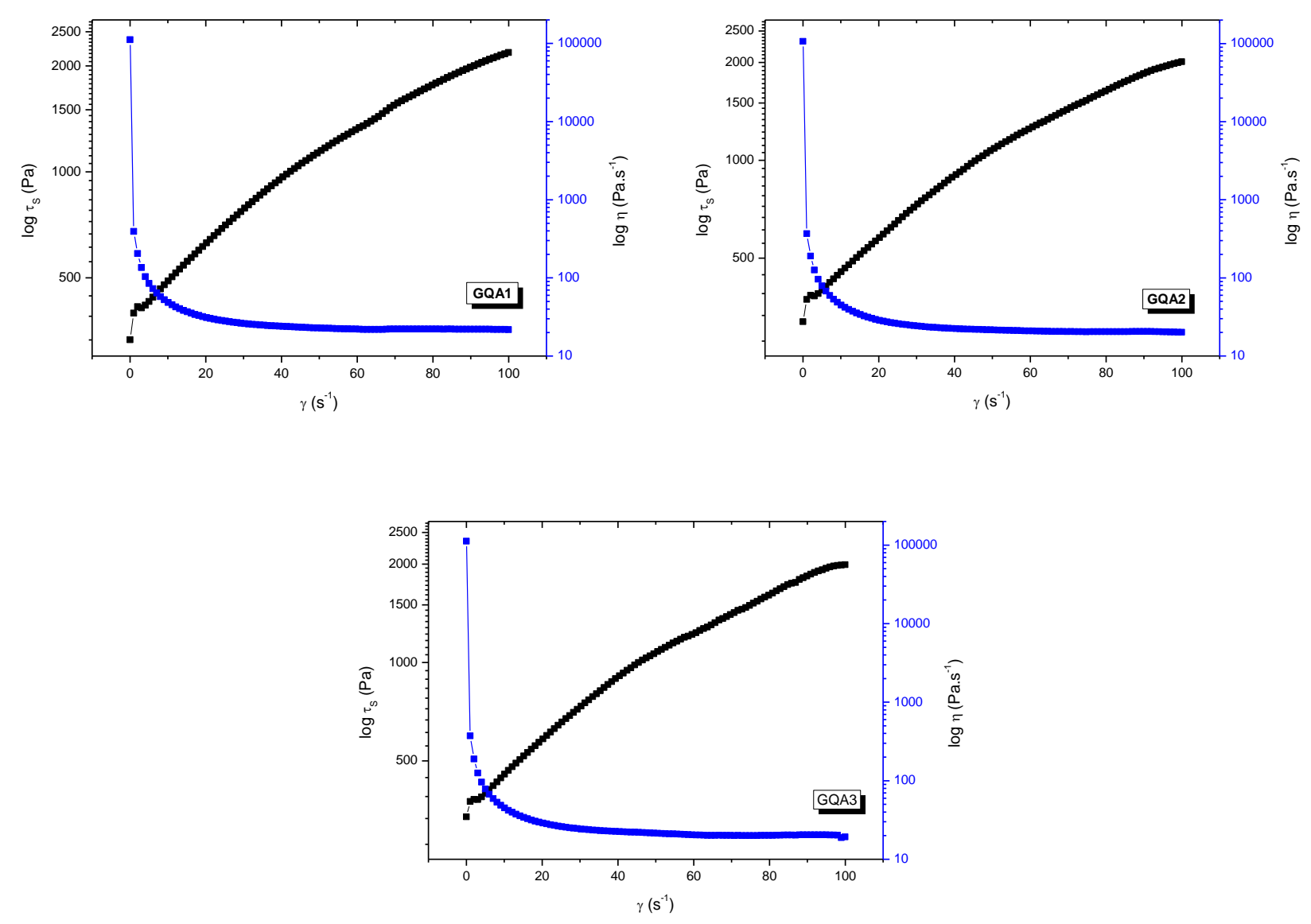

Source: Authors.

Rotta (2008) developed chitosan and hydroxypropylmethylcellulose films and found that in low concentrations of chitosan (1\%) the solutions behaved as Newtonian fluids. In contrast, in higher concentrations (1.5\% to $3.5 \%)$, the solutions showed different rheological properties, acting as non-Newtonian fluids. Similarly, Mendes et al. (2019) produced hydrogels based on polyacrylamide and chitosan for oil sealing in pipelines and observed flow curves similar to those found in this study.

It was possible to conclude that, despite the three concentrations of Aloe vera used, the gels exhibited similar flow curves, reaching a plateau of $5.543 \mathrm{MPa}^{-1}$ in $50 \mathrm{~s}^{-1}$. Although there are different amounts of macromolecules in each formulation, especially of chitosan, the polymer chains present in the gels were capable of moving in a way approximately constant.

Figure 6 illustrates the variation of the storage $\left(G^{\prime}\right)$ and loss $\left(G^{\prime \prime}\right)$ modules of the studied vaginal gels. 
Figure 6. Storage modulus (G') and loss modulus (G”) for Chitosan and Aloe vera gels.
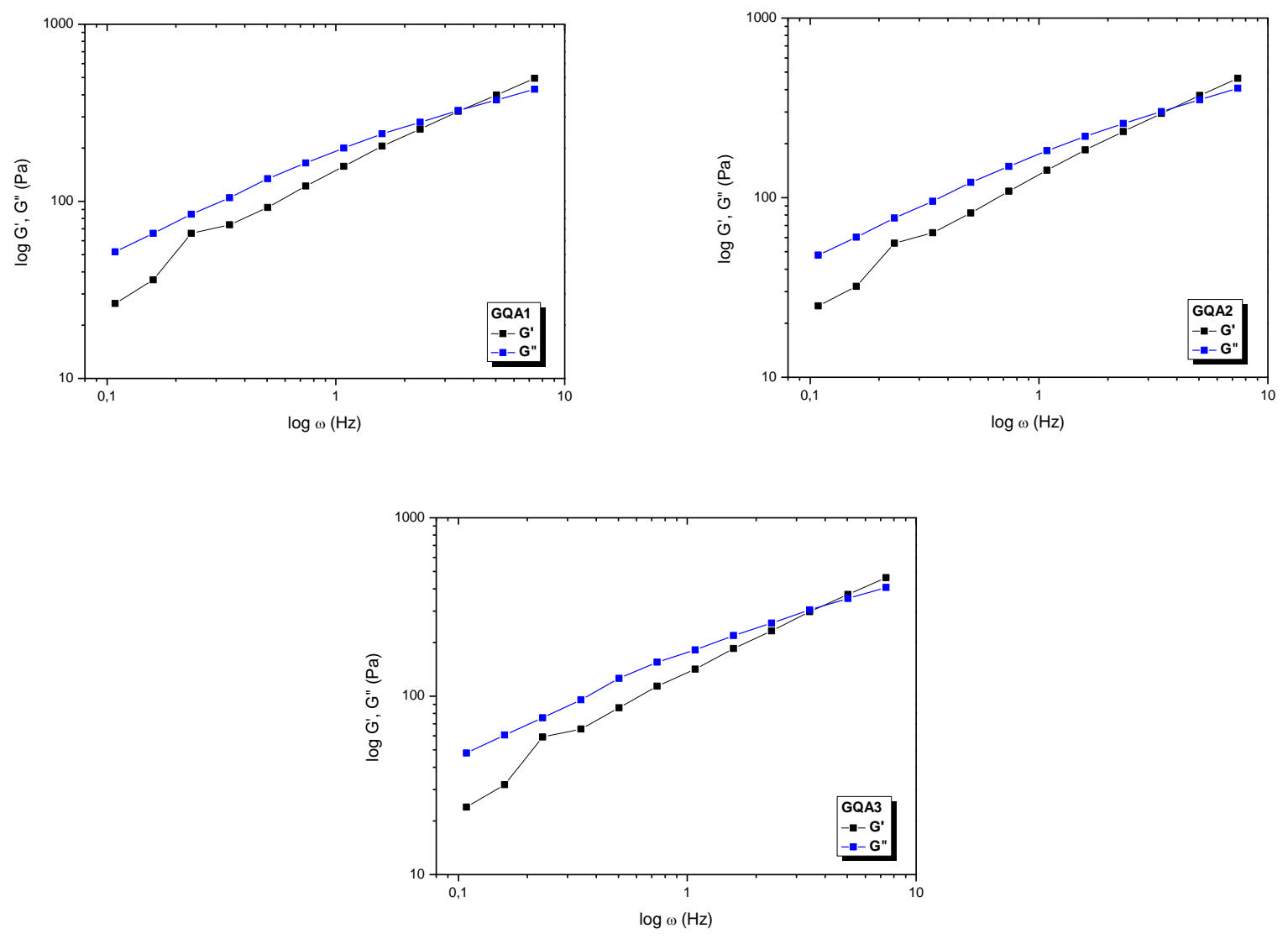

Source: Authors.

As displayed in the figure above, the vaginal gels were characterized by higher $G^{\prime}$ values until the yield point $\left(G^{\prime}=\right.$ G'), located at $3.428 \mathrm{~Hz}$, is reached; from that point onwards, the viscous properties are more pronounced than the elastic ones. Characterized as thixotropic, this category of fluids can easily spread over the application surface when subjected to external pressure, but with enough cohesion so that the product does not drain during the procedure (Melo et al., 2013). It was also found that the curves, although very similar, agreed with the aforementioned rheological behaviors: compositions containing higher concentrations of Aloe vera exhibited lower values of G' and G'.

Similar behaviors were found by Torres (2001), who developed chitosan gels in proportions (\% w/v) of 2.5, 3.0 and 3.5 , using a solution of acetic acid as a solvent. The intersections of curves G' and G” occurred at shear rates of 234,250 and $271 \mathrm{~s}^{-1}$, respectively. In contrast, chitosan gels of different molar masses with econazole nitrate and miconazole nitrate produced by Şenyigit et al. (2014) exhibited lower values of G' and higher G', pointing to a viscous polymer solution. This behavior may be related to possible chemical interactions between the drugs used, or to the frequency range chosen for the scan.

\section{Conclusion}

The compositions presented organoleptic characteristics, $\mathrm{pH}$ values, spreadability, FTIR spectra, and similar rheological properties. Regarding the spreadability of the formulations, we could conclude that the gels will easily spread over the application surface when subjected to external pressure, but with cohesion so that the product does not drain during the 
procedure. In summary, based on our experiments, all formulations show great potential to be used as vaginal gels, in terms of the physicochemical and rheological properties studied.

For future work, it is necessary to evaluate the effectiveness of the vaginal gels on cicatrization and infection control after episiotomy. In this sense, pre-clinical and clinical tests of the gels should be conducted to confirm their effectiveness for use as an adjunct therapeutic agent.

\section{References}

Bonferoni, M. C., Giunchedi, P., Scalia, S., Rossi, S., Sandri, G., \& Caramella, C. (2006). Chitosan Gels for the Vaginal Delivery of Lactic Acid: Relevance of Formulation Parameters to Mucoadhesion and Release Mechanisms. Aaps Pharmscitech, 7(4), 141-147.

Campos, L. M., Lemos, A. S. O., Cruz, L. F., Araújo, M. G. F., Botti, G. C. R. M., Reis Júnior, J. L., Rocha, V. N., Denadai, Â. M. L., Silva, T. P., \& Tavares, G. D (2020). Development and in vivo evaluation of chitosan-gel containing Mitracarpus frigidus methanolic extract for vulvovaginal candidiasis treatment. Biomedicine \& Pharmacotherapy, 130, 110609.

Denari, N. S. M. (2014). Biomateriais binários de quitosana/amido e quitosana/gelatina em L-ácido lático. Masters dissertation. Universidade de São Paulo.

Eghdampour, F., Jahdie, F., Kheyrkhah, M., Taghizadeh, M., Naghizadeh, S., \& Hagani, H. (2013). The Impact of Aloe vera and Calendula on Perineal Healing after Episiotomy in Primiparous Women: A Randomized Clinical Trial. Jornal Of Caring Sciences, 2(4), $279-286$.

Fernando, R. J., Sultan, Ab., H., Kettle, C., \& Thakar, R. (2013). Methods of repair for obstetric anal sphincter injury. The Cochrane Database Of Systematic Reviews, 8(12), 1-45.

Jalalvandi, E., \& Shavandi, A. (2018). In situ-forming and pH-responsive hydrogel based on chitosan for vaginal delivery of therapeutic agents. Journal Of Materials Science: Materials in Medicine, 29(10), 1-11.

Kalis, V., Laine, K., Leeuw, J., Ismail, K. M., \& Tincello, D. G. Classification of episiotomy: towards a standardisation of terminology. Bjog: An International Journal of Obstetrics \& Gynaecology, 119(5), 522-526.

Khoshgozaran-Abras, S., Azizi, M. H., Hamidy, Z., \& Bagheripoor-Fallah, N. (2012). Mechanical, physicochemical and color properties of chitosan basedfilms as a function of Aloe vera gel incorporation. Carbohydrate Polymers, 87(3), 2058-2062.

Liu, C, Chen, X., \& Park, H. (2005). Self-assembled nanoparticles based on linoleic-acid modified chitosan: stability and adsorption of trypsin. Carbohydrate Polymers, 62(3), 293-298.

Llanos, J. H. R., Vercik, L. C. O., \& Vercik, A. (2015). Physical Properties of Chitosan Films Obtained after Neutralization of Polycation by Slow Drip Method. Journal Of Biomaterials And Nanobiotechnology, 06(04), 276-291.

Mastropietro, D. J. (2013). Rheology in Pharmaceutical Formulations-A Perspective. Journal Of Developing Drugs, $2(2), 1$-6.

Melo, E. K. S., Carvalho, A. L. M., Borba, V. F. C., Sousa, G. D., Tabosa, M. A. M., \& Leal, L. B. (2013). Análise e estudo viscosimétrico de diferentes géis de cetoprofeno 2,5\%. Revista de Ciências Farmacêuticas Básica e Aplicada, 34(1), 95-99.

Mendes, M. S. L., Aguiar, K. L. N. P., Pereira, K. A. B., Oliveira, P. F., \& Mansur, C. R. E. (2019). Hidrogéis à base de poliacrilamida e quitosana com potencial aplicabilidade no controle de conformidade em reservatórios de petróleo. Revista Eletrônica Perspectivas da Ciência e Tecnologia, 11 (1), 1-15.

Ribeiro, M. P., Espiga, A., Silva, D., Baptista, P., Hhenriques, J., Ferreira, C., Silva, J. C., Borges, J. P., Pires, E., \& Chaves, P. (2009). Development of a new chitosan hydrogel for wound dressing. Wound Repair And Regeneration, 17(6), 817-824.

Rotta, J., Minatti, E., \& Barreto, P. L. M. (2011). Determination of structural and mechanical properties, diffractometry, and thermal analysis of chitosan and hydroxypropylmethylcellulose (HPMC) films plasticized with sorbitol. Ciência e Tecnologia de Alimentos, 31(2), $450-455$.

Sánchez-Sánchez, M. P., Martín-Illana, A., Ruiz-Caro, R., Bermejo, P., Abad, M. J., Carro, R., Bedoya, L. M., Tamayo, A., Rubio, J., \& Fernández-Ferreiro, A. (2015). Chitosan and Kappa-Carrageenan Vaginal Acyclovir Formulations for Prevention of Genital Herpes: In Vitro and Ex Vivo Evaluation. Marine Drugs, 13(9), 5976-5992.

Santos, L. M., Santos, L. M. S., Brandão, M. M., Cerqueira, E. A. C., Ramos, M. S. X., \& Carvalho, E. S. S. (2018). Associação entre perineorrafia e problemas perineais, atividades habituais e necessidades fisiológicas afetadas. Revista Cuidarte, 9(2), 2233-2244.

Santos, R. C. S., \& Santos, R. G. (2016). Fatores relacionados com a prática da episiotomia no Brasil: revisão de literatura. Estação científica (UNIFAP), 6(1), 43-52.

Şenyigit, Z. A., Karavana, S. Y., Eraç, B., Gürsel, Ö., Limoncu, M. H., \& Baloğlu, E. (2014). Evaluation of chitosan based vaginal bioadhesive gel formulations for antifungal drugs. Acta Pharmaceutica, 64(2), 139-156.

Sharma, A. (2020). Honey Aloevera loaded electrospun PVA nanofibers as a potential wound dressing material. http://teqip.iith.ac.in/wpcontent/uploads/2018/10/Apeksha.pdf

Sioutis, D., Thakar, R., \& Sultan, A. H. (2017). Overdiagnosis and rising rate of obstetric anal sphincter injuries (OASIS): time for reappraisal. Ultrasound In Obstetrics \& Gynecology, 50(5), 642-647. 
Research, Society and Development, v. 10, n. 6, e36310614895, 2021

(CC BY 4.0) | ISSN 2525-3409 | DOI: http://dx.doi.org/10.33448/rsd-v10i6.14895

Teplicki, E., Qianli, M. A., Castillo, D., Zarei, M., Hustad, A. P., Chen, J., \& Li, J. (2018). The Effects of Aloe vera on Wound Healing in Cell Proliferation, Migration, and Viability. Wounds, 30(9), 263-268.

Torres, M. A. (2001). Propriedades viscosas e viscoelásticas de soluções e géis de quitosana. Masters dissertation. Universidade Estadual de Campinas.

Valenta, C. (2005). The use of mucoadhesive polymers in vaginal delivery. Advanced Drug Delivery Reviews, 57(11), 1692-1712.

Verghese, T. S., Champaneria, R., Kapoor, D., \& Latthe, P. M. (2016). Obstetric anal sphincter injuries after episiotomy: systematic review and meta-analysis. International Urogynecology Journal, 27(10), 1459-1467.

Wang, H., Zhang, X., Mani, M., Jaganathan, S., Huang, Y., \& Wang, C. (2017). Microwave-Assisted Dip Coating of Aloe Vera on Metallocene Polyethylene Incorporated with Nano-Rods of Hydroxyapaptite for Bone Tissue Engineering. Coatings, 7(11), 182-199.

Wu, Q., \& Li, L. (2020). Thermal sensitive Poloxamer/Chitosan hydrogel for drug delivery in vagina. Materials Research Express, 7(10), 105401. 